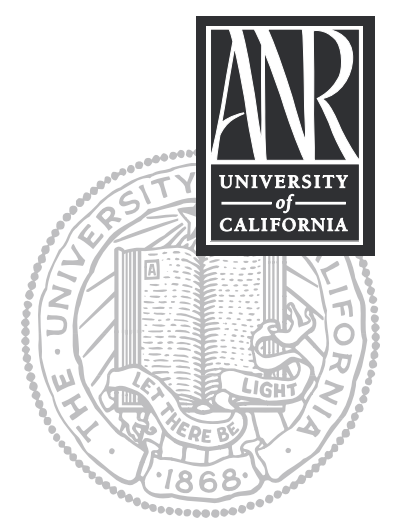

UNIVERSITY OF CALIFORNIA

Division of Agriculture and Natural Resources http://anrcatalog.ucdavis.edu

\title{
Small-Parcel Landowner's Guide to Woodland Management
}

DOUGLAS D. McCREARY, Natural Resources Specialist, Integrated Hardwood Range Management Program, Sierra Foothill Research and Extension Center, University of California; and GLENN NADER, UCEE Livestock and Natural Resources Farm Advisor for Butte, Yuba, and Sutter Counties

\section{INTRODUCTION}

The foothills of the Sierra Nevada, Coast, and Transverse Mountain ranges are becoming increasingly attractive to people who want to relocate away from crowded urban areas and live in a more rural setting. These areas are considered desirable places to live because of their natural beauty, moderate climate, and slower-paced lifestyle (fig. 1). Historically, California's foothills were often the sites of large ranches, but in the last few decades many of these ranches have been sold and parceled out into ranchettes or rural subdivisions.

While focusing on California's native oak trees, this publication is meant to help the owners of small woodland properties better understand the natural environment they are now living in and manage their resources more effectively. It was written in response to the many inquiries that Cooperative Extension offices have received from new residents in California's foothills. Clearly, people want to know as much as possible about their new home and learn how to make the most of their new environment. This is not surprising, since one of the main reasons urban dwellers move to the foothills is for the natural resources. We begin with brief descriptions of some of the more important plants and animals found in the foothills, and then discuss certain activities that should be avoided to insure the long-term health of wildlife and native vegetation. We end with some recommendations about management activities that landowners can undertake to protect their property, enhance the natural resources, and make the most out of their new environment.

Figure 1. Many people move to

California's oak-covered foothills because of the beauty and serenity, as well as the slower-paced lifestyle. Photo: Jack Clark.

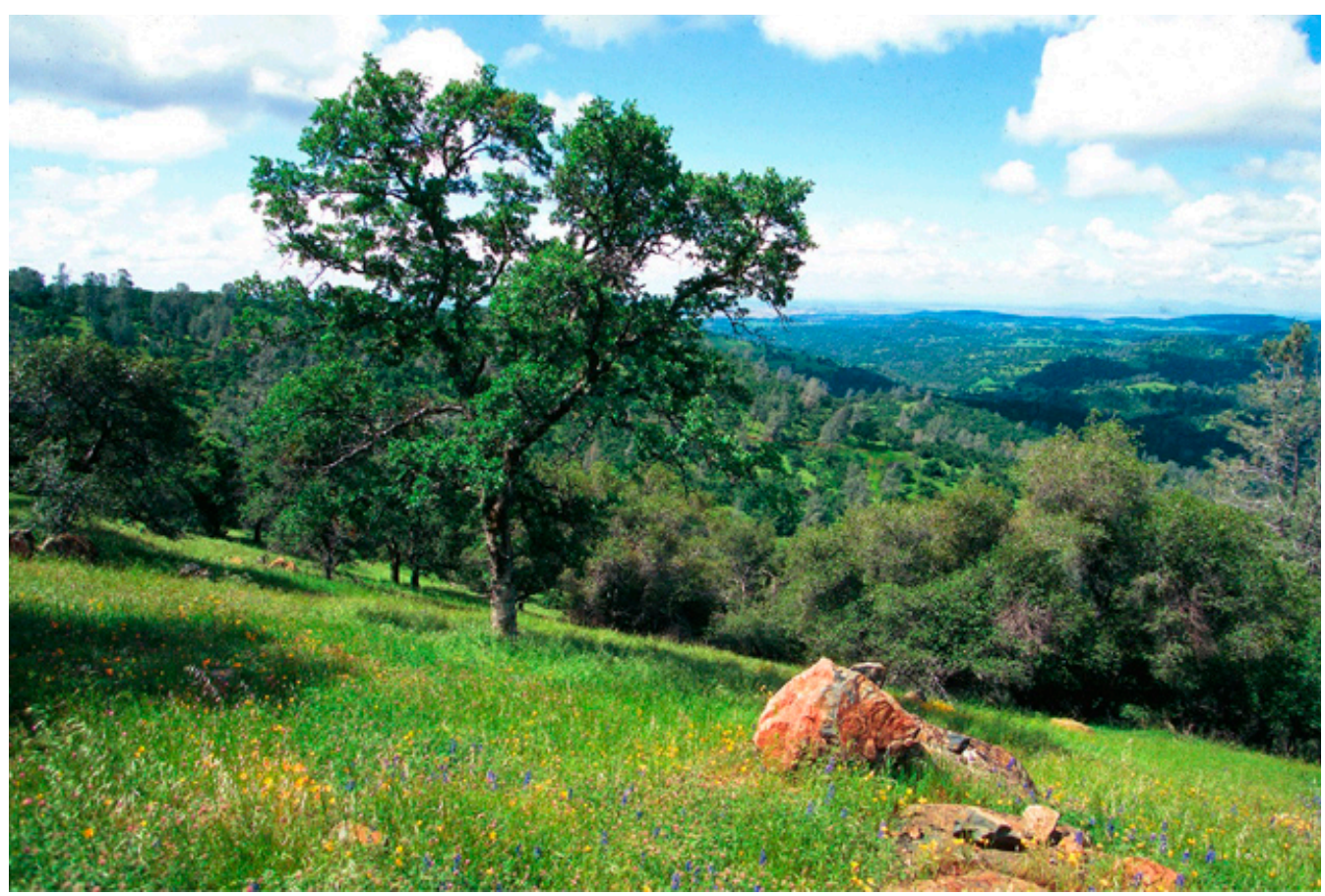




\section{IMPORTANCE OF FOOTHILL ECOSYSTEMS}

\section{Oaks that Grow in the Foothills}

The most common trees on many foothill lands are oaks. California is blessed with 20 native oak species and several of these are the principal tree species on low-elevation foothills. Some of the more common species are blue oak (Quercus douglasii), valley oak (Q. lobata), black oak (Q. kelloggii), interior live oak (Q. wislizenni), canyon live oak (Q. chrysolepis), and coast live oak (Q. agrifolia). The live oaks are evergreen and retain foliage throughout the year. The other species are all deciduous, losing all of their foliage in the late fall before growing a new crop of leaves the following spring. Blue oak and interior live oak often grow together with foothill pine (Pinus sabiniana) in foothill areas below 3,000 feet. Valley oak is more common at lower elevations, and is most often found where soils are deep and moisture is abundant. It is the largest of the California oaks and can grow rapidly. Black oak usually grows at higher elevations, especially in the Sierra Nevada, and is often a component of mixed conifer forests above 3,000 feet. Canyon live oak is one of the most widely distributed of the oaks, occurring from Oregon to Mexico. It generally prefers steep, rocky canyons, hence its name. Coast live oak is restricted to the coastal mountains and does not naturally grow more than 50 miles from the Pacific.

\section{Foothill Wildlife}

Aside from their beauty and the distinctive character they contribute to the landscape of the foothills, native oaks and oak woodlands are vital to a wide range of wildlife. More than half of the 660 terrestrial vertebrates that live in California spend at least part of the year in oak woodlands. The trees provide food, shelter, and a hospitable environment. Acorns are a critical food source for a wide range of birds and mammals including deer, bear, squirrels, turkeys, pigs, jays, and acorn woodpeckers. But oaks provide other critical resources as well. Older, decadent trees, as well as snags (standing dead trees), provide locations where cavity-nesting birds can excavate homes. Downed logs can provide protection for amphibians and reptiles. And the cracks and fissures in the bark of trees harbor insects that are devoured by many species of birds. Without the oak trees, many of these wildlife species could not survive in the foothills (fig. 2).

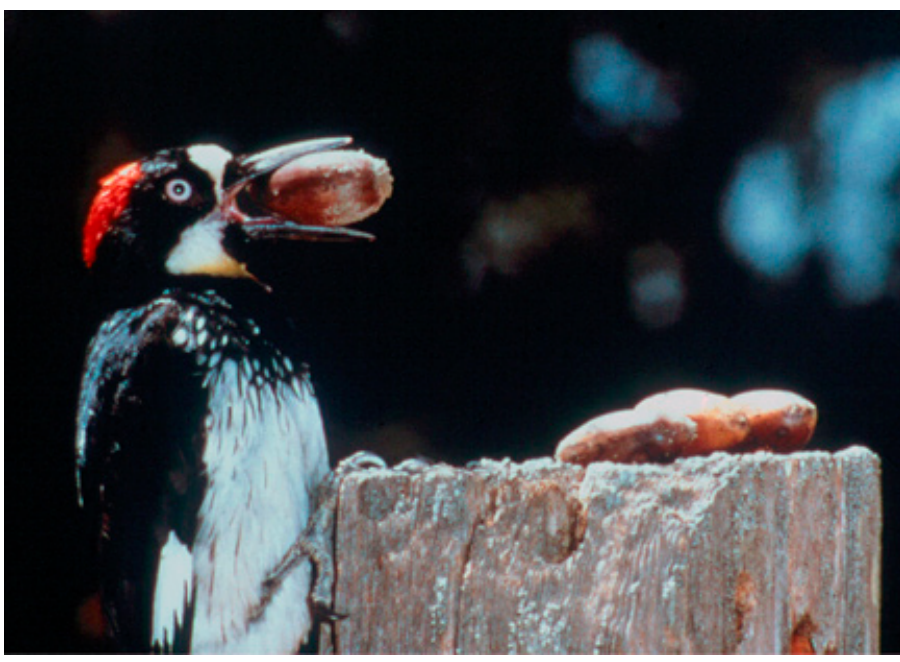

Figure 2. Many species of wildlife use oak woodlands at some time during the year. Acorn woodpeckers are very dependent on oak trees, collecting and storing acorns to be eaten later during the winter.

\section{Understory Vegetation}

While oaks are the prominent overstory vegetation on many foothill woodlands, other types of plants grow in these areas as well. Many shrubs including manzanita, ceanothus, poison oak, coffee berry, and toyon are common associates of the oaks in these landscapes. A wide variety of grasses and forbs also grow on these lands. Many of these forage plants are actually not native to California but are annual plants that were introduced from the Mediterranean region when Europeans first came here. These plants originated in an environment similar to California. As a result, after being introduced here, they spread rapidly and displaced native perennial bunch grasses in many cases. The golden-brown foothills that we see today, which are such a distinctive feature of the state's landscape, are actually that color because they consist mainly of non-native grasses that die in the late spring or early summer. 


\section{Invasive Weeds}

In the recent years there has been a great deal of interest in reestablishing native perennial bunch grasses in certain areas of the state and returning these lands to a vegetative complex similar to what it was before European settlement. In most locations, however, the introduced annuals are here to stay. On the plus side, these plants are often highly nutritious and are excellent feed for domestic livestock, as well as for native herbivores. Unfortunately, this cannot be said for certain noxious weeds such as yellow starthistle and medusahead. These plants have little redeeming value (other than, perhaps, as flowers for honey) and there is a concerted effort at controlling them since they are such vigorous competitors and have taken over vast areas of foothill woodlands. Both were introduced into California over 100 years ago, though for many decades they spread slowly and caused little concern. Today, however, it is estimated that medusahead grows on over a million acres in the western states and starthistle occurs on approximately 10 million acres in California alone. If you have these species on your property, contact your local University of California Cooperative Extension Office about recommended treatments. Both can be reduced if they are grazed heavily early in the season while they are still relatively palatable to livestock. Later in the season, medusahead can be controlled using prescribed burning, while some selective herbicides can be used to limit starthistle. However, single treatments rarely provide long-term control, and it is usually necessary to repeat treatments.

\section{ACTIVITIES THAT CAN IMPACT OAKS}

\section{Roads/Grading/Trenching/Backfilling}

Native California oaks are relatively resistant to natural damaging factors. While there are many insects and diseases that can adversely affect different life stages of trees in their natural environment, rarely are there widespread outbreaks where large numbers of trees are killed. However, in a managed landscape where human activities disturb them, damage to oaks, albeit inadvertent, is often deadly. This is especially true in areas where trees are adjacent to buildings, roads, or utilities. Their root systems are particularly vulnerable, and changes in their roots' environment should be avoided. Since the majority of an oak's root system is in the top 3 feet $(0.9 \mathrm{~m})$ of the soil, impacts in this area can adversely affect the root system and its ability to take up moisture and nutrients. Driving or parking heavy equipment over soil under the tree's canopy can seriously compact the soil and, in effect, suffocate the tree's roots. This occurs when the soil

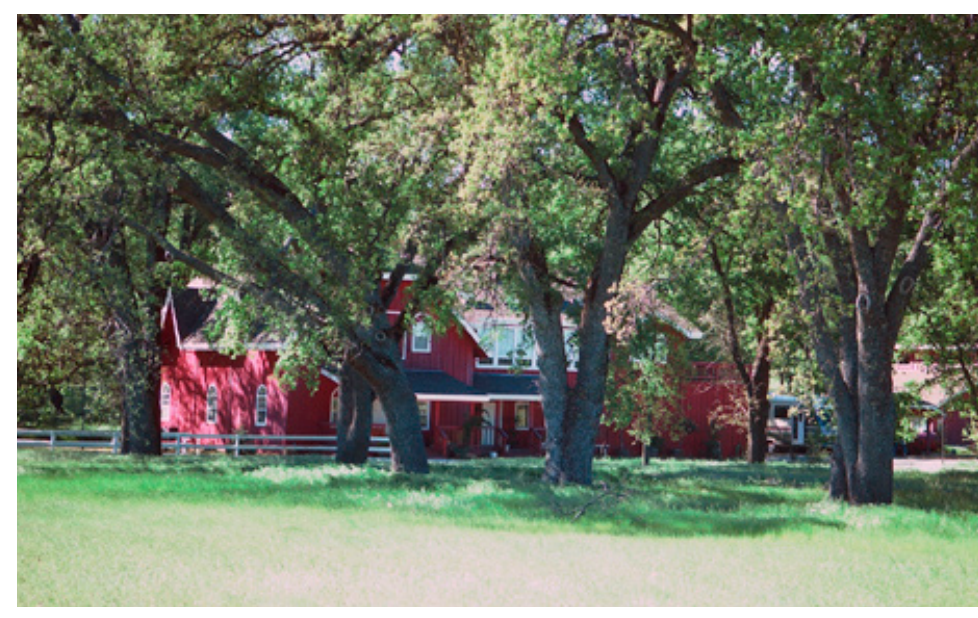

Figure 3. Oak trees are often a focal point of landscaping around foothill houses. Homeowners need to understand that some practices, such as grading and summer irrigation, can damage oaks and should be avoided. Photo: Douglas McCreary. pores are compressed, preventing the roots from taking up oxygen. The chance of this type of compaction increases dramatically when the soil is wet, since wet soils compress far more easily than dry soils. To prevent compaction, vehicles should not be driven or parked under trees during construction, especially when the soil is wet. For the same reason, any grading or backfilling near trees should be avoided; grading can directly damage shallow roots and backfilling can limit air transfer and can suffocate them (fig. 3). Finally, trenching poses a significant risk since it invariably severs roots; the closer the trench is to the tree's main trunk, the greater the damage becomes. If trenching under an oak is absolutely necessary, try to plan so that only one trench is required and all of the utilities, including plumbing, electricity, telephone, and cable, are 
consolidated. Better yet, do not excavate the trenches with backhoes. Rather, hand dig them and avoid cutting large roots. In some cases, trenches can also be excavated using high-pressure water or air, which can greatly reduce root damage.

\section{Summer Irrigation}

Even if oaks are protected during construction and adverse impacts to the trees are minimized, they can still be damaged by summer irrigation. Oaks have evolved in a Mediterranean-like environment where there is a long dry period that coincides with warm summer weather and a wet period that coincides with cool winter weather. When a lawn or other moisture-loving plants are planted under an oak tree, it is usually necessary to irrigate them during the summer. This moisture creates warm, wet conditions in the soil that do not occur in Mediterranean environments. Such environmental conditions promote the growth of several harmful soil pathogens including crown rot and oak root fungus. Under warm, moist conditions these pathogens proliferate, feeding on the tree's roots and eventually killing them. This can so weaken the tree that it falls over and dies. A good rule of thumb is to avoid planting anything under the canopy of existing oaks that will require summer irrigation.

\section{Grazing Animals}

The most obvious impact to oaks from livestock is the browsing of young seedlings. Cattle, sheep and goats will all browse small oak seedlings and will also clip the shoots off of larger trees. This browsing of oaks is most pronounced after the annual grasses dry up and the oaks are one of the few green plants in the pastures. Signs of browsing on mature trees are the lack of low branches in heavily grazed pastures. The animals often clip off any foliage within their reach, causing all of the trees to appear pruned, with little or no foliage within 4 to 5 feet $(1.21 .5 \mathrm{~m})$ of the ground. This is usually not terribly damaging to large trees, since the majority of their foliage is not affected. However, it can be extremely damaging, and even lethal, to small seedlings. Fortunately, oaks have the ability to "sprout back," even if every leaf has been clipped off. They can therefore remain alive in a stunted condition for decades if they are repeatedly browsed. But there are limits to this ability; without leaves, plants cannot photosynthesize and manufacture the food necessary for metabolic activity. Yearly defoliation may make the seedlings so weak that they eventually die.

In addition to browsing, livestock can indirectly impact oak seedlings by reduc-

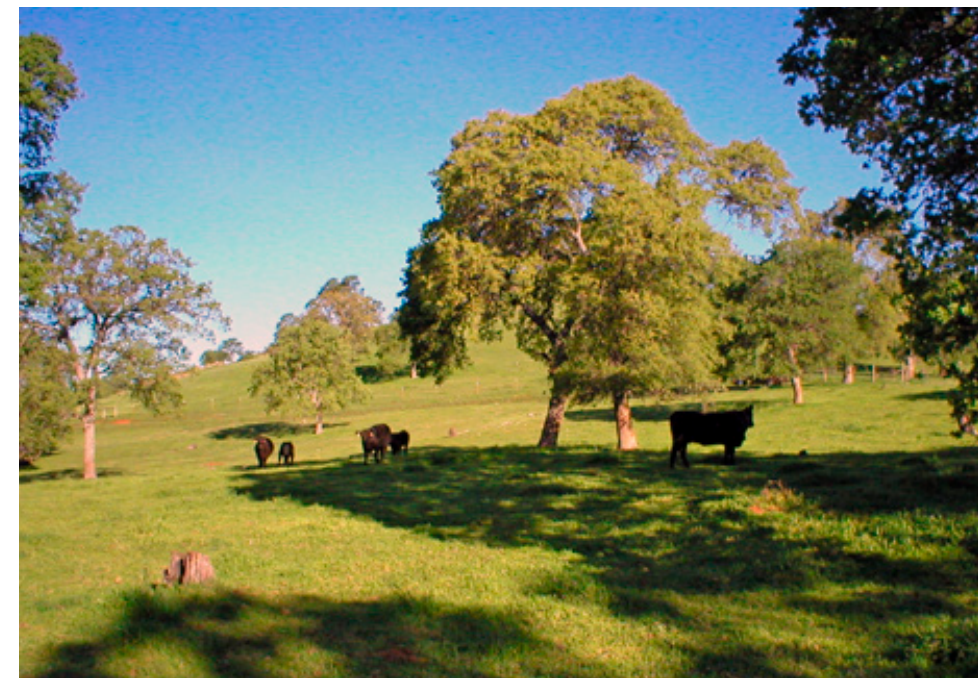

Figure 4. Most of California's oak woodlands are privately owned and the principal economic activity there is livestock grazing. It takes from 8 to 22 acres to feed a single cow for a year. ing organic matter and compacting the soil. Studies have shown that in grazed pastures the soil has a higher bulk density (it is more compressed) and there is less organic matter. Both of these conditions make it more difficult for young oak seedlings to become established and grow well, even if acorns have germinated and sent down a root. Some have suggested that two centuries of fairly continuous grazing on many hardwood rangelands in California may have changed soil conditions so much that it is much more difficult for oak seedlings to become established today, helping to create the "oak regeneration problem" that has been reported for three of the state's 20 native oak species.

Moderate grazing (10 to 20 acres, or 4.0 to 8.0 ha, per cow) during the green grass period is recommended in regeneration areas (fig. 4). 
Consider planting oaks away from livestock water sources and areas where salt or supplement is placed, as these areas have higher livestock use. Also consider planting on steeper slopes where cattle graze less. Tree shelters and metal fence posts can help protect planted oaks from cattle damage in grazed pastures, though their efficacy is limited in heavily grazed areas since the animals can rub against them and knock them over. Research indicates that oak trees over 6.5 feet $(2.0 \mathrm{~m})$ tall are less likely to be impacted by moderate grazing.

\section{Horse Damage}

Horses can seriously damage mature oaks by stripping the bark off the trees. In severe instances, horses can girdle most of the trees in a pasture, removing the bark from the tree's base all the way up to as high as they can reach, which can be 8 feet $(2.4 \mathrm{~m})$ or more. If a tree's bark is removed all the way around, the top of the tree will eventually die, though it may take two or three years. Most believe that this type of horse behavior results from lack of food or nutritional deficiencies, which the animals are trying to compensate for by eating the bark. However, the reasons for this behavior are probably not always the same. Sometimes it seems horses will begin chewing the bark from trees simply out of boredom. This can occur in confined areas where there is not much to keep the horse occupied.

So, what can be done to protect the trees where horses pose a threat? If the cause is diet or nutrition, providing additional food or supplements to the animals may eliminate the behavior. In extreme cases, the offending animals may have to be pastured in areas where no trees are present. If this is out of the question, it may still be possible to protect individual trees by building exclosures around them or wrapping the trees with fencing. However, to prevent long-term tree damage, it is important that the fencing be loose enough so the tree does not eventually outgrow it, causing it to become imbedded it the bark.

Horses are also very large animals that can damage trees by compacting the soil. If the pasture is small and the horses regularly stand in groups under specific trees, they can seriously compact the soil in those areas and thereby suffocate the trees' roots. As noted in the discussion of vehicle compaction above, this type of compaction increases dramatically when the soil is wet. To prevent this from happening, horses (and cattle, for that matter) should be prevented from congregating under trees during wet conditions.

\section{Fires}

Fires are becoming an increasing threat to oak woodland vegetation, as well as to the structures built in the foothills. In part, this is because most fires have been actively suppressed during much of the last century. This has resulted in an accumulation of fuels in many foothill locations, increasing the risk that fires will become large in scope once they do start. As for the trees themselves, oaks have evolved mechanisms to survive periodic burning. Moderate and even low-intensity fires can scorch all the leaves on woody plants. For most conifers such damage is usually lethal. Oaks, on the other hand, suffer little long-term damage from the burning of their foliage. If a fire happens early in the growing season, the trees may grow new leaves before autumn; by the end of the year, it may be difficult to tell which trees were scorched in the fire. If a fire occurs in the summer, the oaks usually will not produce a complete crop of new leaves until the following spring. Following such fires, the trees can appear dead, since all leaves are brown and brittle and the trunks may be blackened. But many of these trees will survive and it is important that landowners understand this; otherwise, some may want to cut these trees down, believing they will not recover. It is 


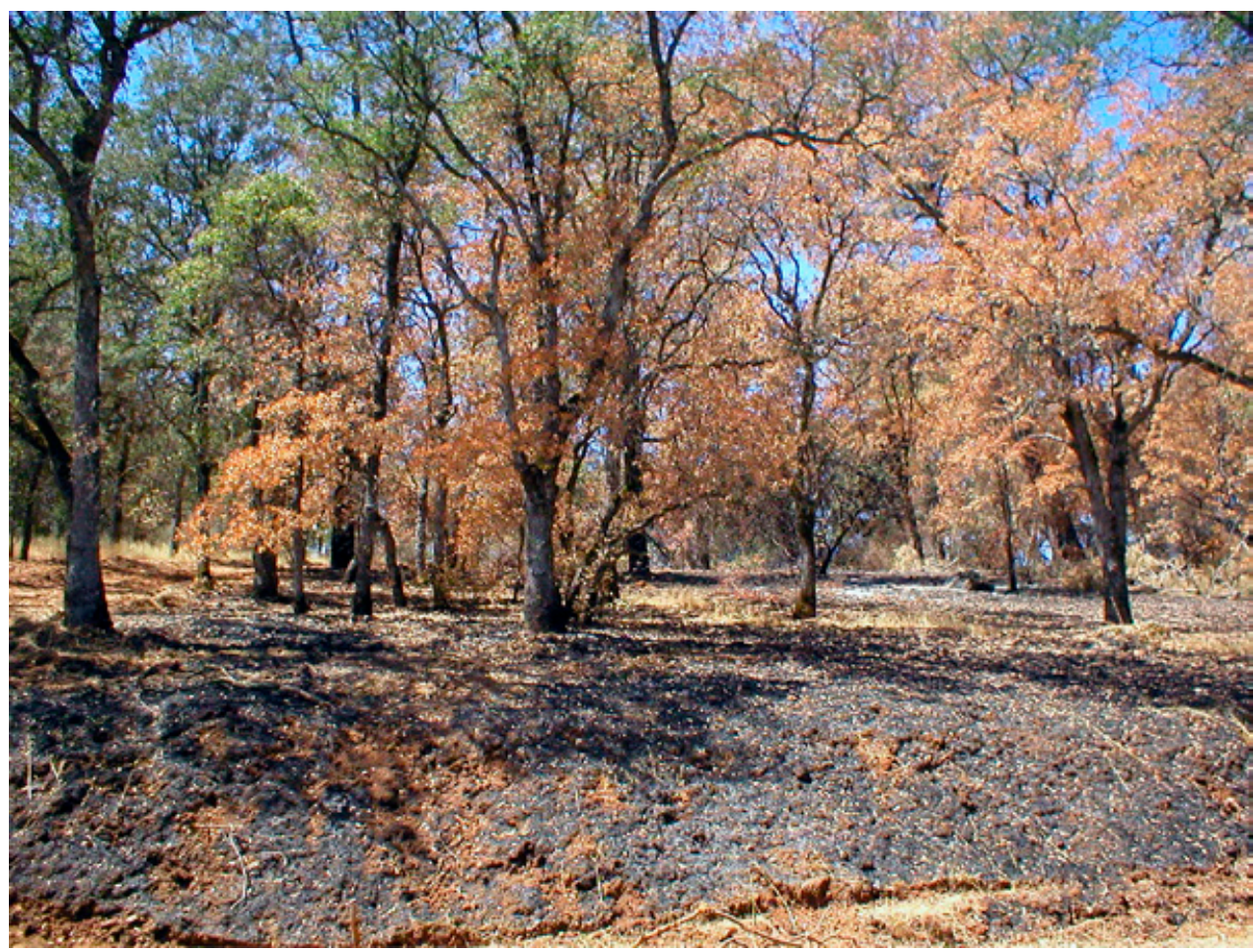

Figure 5. Fire is a natural process in oak woodlands, but as more people move here, fire can have deadly consequences. Oaks have evolved so that they can survive low-intensity fires, even when their leaves are scorched and have turned brown.

Photo: Douglas McCreary.

therefore generally a good practice to wait at least a year after a fire to determine if a tree has died and should be removed (fig. 5).

More severe fires can kill the tops of oaks if the cambium has been heated to lethal temperatures. The cambium is the area immediately under the bark where cell division and radial diameter growth occur. If the cambium has been heated so severely that it has been killed all the way around, the top of the tree will eventually die, since the apparatus that transports food within the tree has been destroyed. However, by merely looking at the outside of the trunk, it is often difficult to tell if the cambium has been killed. Fires that have scorched the bole and turned it black are not necessarily hot enough to kill the cambium-especially on trees that have a larger diameter and thicker bark. This is because bark is a good insulating material; the thicker it is, the better it prevents heat damage underneath. However, if the fire has been hot enough to actually burn into the bark and reduce its thickness, the cambium is usually killed. One can often determine the severity of damage by cutting into and under the bark to observe the cambium. Healthy cambium is white and moist, while dead cambium is usually brown and partially dried out.

Even if an oak has been girdled and the aboveground portion of the tree has been killed, most oaks will sprout from their base the following year. Sprout-origin trees initially produce many new shoots. These sprout clumps thin out over time, although even mature trees that started as sprouts usually have multiple trunks. In general, live oaks are more vigorous sprouters than deciduous oaks. Likewise, trees with a smaller diameter are more likely to sprout than those with a larger diameter, although all California oak species will sprout. Oaks in moister areas also generally sprout better than those growing on dry sites. Many of the oak trees in California today originated as sprouts following fire and can be recognized because they have several main trunks. Sprout-origin trees generally grow faster than young seedlings starting from acorns. This is because they have a massive root system compared to a newly germinated acorn. As such, they have access to greater amounts of water and 
nutrients to support top growth. There is evidence that pruning sprout clumps back to two or three dominant shoots can accelerate their growth and reduce the time it takes for these sprouts to grow back into a tree.

\section{Firewood Harvesting}

Most people know that oak firewood burns longer and hotter than softwoods such as pine or fir. It is therefore natural for foothill landowners who heat with wood to utilize some of the oak trees on their parcels for firewood. In many cases people merely use trees that have died or fallen down from natural causes. But before one removes all of this dead material, it is important to remember that certain species of wildlife require dead trees, both standing and fallen, for their habitat. If you are considering thinning your oak stands and cutting down some trees for firewood, there are additional considerations to keep in mind. First, oak trees on hardwood rangelands generally grow very slowly. If you have a chance to look at the annual growth rings on a harvested tree, you will see that it can often take 20 years or more for the trees to grow an inch in diameter. To manage a firewood operation sustainably, you should only harvest as much wood as grows. On moderately stocked hardwood rangelands, this can be about one-tenth of a cord per acre per year. Therefore, if you have a 10acre (4.0 ha) parcel, you could sustainably harvest about one cord per year without decreasing the overall wood volume.

Some have suggested that the pressure to harvest oaks for firewood could be reduced if other, faster-growing species were planted and grown for firewood. Several years ago studies were conducted at the UC Sierra Foothill Research and Extension Center in Yuba County to evaluate the ability of several species of eucalyptus to produce wood. It turned out that if there was an abundant source of inexpensive water for irrigation (a big "if" for many properties), the fastest-growing eucalyptus species produced as much as 10 cords per acre per year. This was 100 times the amount produced by many naturally growing oak stands. Clearly, growing eucalyptus rather than harvesting oaks may be an option some foothill landowners should consider. It should be noted that while we generally would not recommend planting non-native trees such as eucalyptus (originally from the southern hemisphere, but planted widely in California during the late 19th and early 20th centuries), the risk of spread is small and the benefits appear great; in this case, therefore, we make an exception to the normal rule.

\section{OAK REGENERATION}

\section{Poor Natural Regeneration}

Several oak species, including blue oak, valley oak, and Engelmann oak (Q. engelmannii), are not regenerating well in certain locations in California. The reasons for this inadequate regeneration are often site specific and include livestock grazing, herbivory from wildlife, and intense competition from dense annual grasses. Poor oak regeneration is not a problem everywhere; it is most pronounced in areas of low rainfall, shallow soil, and on sites where plant competition and animal pressures are intense. This problem is a serious concern, since without adequate seedlings and saplings to replace mature trees that die naturally or are removed, woodland sites could convert to grasslands or become areas dominated by shrubs.

\section{Artificial Regeneration}

For those concerned about poor oak regeneration on their properties, techniques have been developed to artificially establish young oaks. The most critical factors are the 


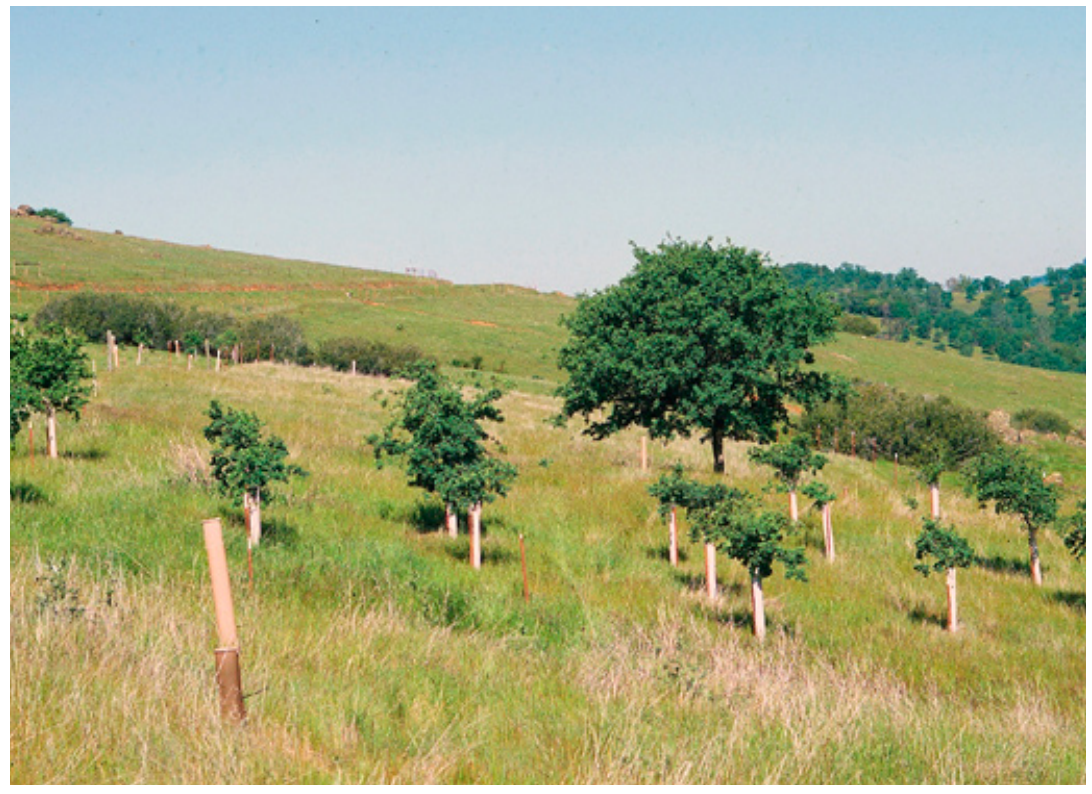

Figure 6. In portions of California certain species of oaks have not been regenerating well. UC researchers have studied how to successfully grow and establish oaks in areas where they have disappeared. Here tree shelters helped get oaks established. Photo: Jack Clark. protection and maintenance of seedlings in the field, especially during the first 2 to 3 years after planting. Protecting seedlings is essential, since a wide range of animals are intent on eating young oaks. These include insects such as grasshoppers, rodents such as gophers, and large herbivores such as deer and cattle. A number of devices have been used to protect oak seedlings from animal damage, but the most useful we have found are called treeshelters. These are double-walled, plastic tubes that are placed over individual seedlings. If properly secured, these devices can successfully protect seedlings from a wide range of animals including all of those mentioned above. In addition, treeshelters act like mini-greenhouses and stimulate the aboveground growth of seedlings (fig. 6).

There has not been a great deal of research on how long treeshelters should be kept on the seedlings. But, since treeshelters tend to initially promote shoot growth at the expense of root growth, during the first two years the seedlings tend to be tall and spindly. If shelters were removed during this period, the seedlings would likely not be sturdy enough to remain upright and thus would fall over. We have found that it is best to keep the shelters on for at least three years after the seedlings have grown up and out of the tops of the shelters. During this latter interval, the seedlings tend to develop much more girth (while height growth slows down) and become much sturdier and able to stand upright when the shelters are removed. There is also limited evidence suggesting that in areas grazed by cattle, seedlings should be protected until they are at least 6.5 feet $(2.0 \mathrm{~m})$ tall. Browsing damage to seedlings of this height or taller has been found to be significantly less than it is for seedlings shorter than this.

The other major threat to oak seedlings is plant competition. As stated above, many oak woodlands today are dominated by introduced Mediterranean annuals. These plants are vigorous competitors, especially in the spring when acorns are germinating and young oaks are trying to send down roots. During this period, annuals put all of their energy into growing and producing seed before dying in the late spring or early summer. As a result of the competition from grasses and forbs, the amount of moisture available to oaks may be insufficient to allow them to survive and grow. It is therefore essential that areas around planted oaks be kept weed free for 2 to 3 years after planting. Generally, we recommend that vegetation within 2 feet $(0.6 \mathrm{~m})$ of seedlings be removed. This can be accomplished in a number of ways including hoeing, using herbicides, or placing mulch around seedlings. In addition to reducing competition, weed removal also lessens the likelihood of damage to seedlings from animals that live in dense grass such as meadow mice (or voles) and grasshoppers.

\section{CONCLUSIONS}

Oak woodlands are a vital resource in many foothill areas of California. They provide a beautiful and distinctive character to the landscape, protect soils, offer recreational opportunities, and harbor a wide range of wildlife. These trees also benefit the new residents who live among them on small parcels. But oak woodlands present 
challenges also, and these properties must be managed carefully. Doing so will help ensure that the resources and amenity values provided by the oaks are conserved into the future. With some knowledge about how the plants, animals, and other natural resources function and interact, as well as a commitment to managing oak woodlands sustainably, it is possible not only to enjoy living in this new environment but to use the resources available there for a range of benefits.

\section{BIBLIOGRAPHY}

Throughout this publication we have referred to various studies, reports, or publications that document some of the points made. These sources are listed below, and they provide additional details about a wide range of activities such as enhancing wildlife on woodland properties, regenerating oaks, and growing firewood.

Johnson, S. G. n.d. Living among the oaks. University of California Division of Agriculture and Natural Resources, Publication 21538. Living Among the Oaks is a colorful, 8-page publication prepared by the Integrated Hardwood Range Management Program. It presents practical information on protecting and enhancing native oaks that grow on California rangelands, especially in areas of subdivision and urbanization. It provides a valuable resource for small parcel owners, arborists, homeowner associations, municipal planners, and anyone with an interest in California's valuable oak resources. Order on the IHRMP Web site at http://danr.ucop.edu/ihrmp/. Or see "For Further Information" below.

Johnson, S. G.; W. D. Tietje, ed. n.d. Wildlife among the oaks: A management guide for landowners. University of California Division of Agriculture and Natural Resources, Publication 21537. Wildlife Among the Oaks provides up-to-date information on how the owner of a home, ranch, or ranchette can attract and maintain oak woodland wildlife. It covers the interdependence of oaks and wildlife, and gives tips on managing special oak habitat resources for wildlife and sharing your land with wildlife. Several "Prescription Cards" highlight interesting and useful facts on individual oak woodland wildlife species and describe their habitat requirements. Each section is richly illustrated with color photography and artwork of oak habitats and wildlife. Order on the IHRMP Web site at http://danr.ucop.edu/ihrmp/. Or see "For Further Information" below.

McCreary, D. D. 2001. Regenerating rangeland oaks in California. Oakland: University of California Division of Agriculture and Natural Resources, Publication 21061. This 62-page publication provides step-by-step procedures for successfully regenerating native California oaks that grow on rangelands. It contains chapters on the reasons for poor oak regeneration, how to collect, store, and plant acorns, how to grow oak seedlings, and planting and maintaining seedlings in the field. See order instructions on the IHRMP Web site at http://danr.ucop.edu/ihrmp/. Or see "For Further Information" below.

2004. Fire in California's oak woodlands. Berkeley: University of California Integrated Hardwood Range Management Program. This 8-page publication describes fire history in oak woodlands, current threats, and steps landowners can take to minimize the risks and impacts of a fire. It also discusses how oak trees have adapted to fire and how to assess whether or not oaks have been killed by a fire. Available for free downloading at http://danr.ucop.edu/ihrmp/. 
n.d. How to grow California oaks. Oakland: University of California Division of Agriculture and Natural Resources, Publication 21540. This 4-page publication gives an overview on how to regenerate rangeland oak species. It covers a variety of topics and is a useful guide for restoration professionals, community groups, and homeowners. A list of native plant nurseries providing oak seedlings is also included. Available for free downloading at http://danr.ucop.edu/ihrmp/. Or see "For Further Information" below.

Thomson, C. D. 1996. Yellow starthistle: Biology and control. Oakland: University of California Division of Agriculture and Natural Resources, Publication 21541. This document details all the methods important in the effort to control this rapidly expanding range weed, which is poisonous to young horses and is often a fire hazard. It is illustrated with color photos. Available from the UC ANR Publications Web site at http://anrcatalog.ucdavis.edu.

Tietje, W. 1990. Harvesting firewood for sustained yield on oak rangelands. Oakland: University of California Division of Agriculture and Natural Resources, Publication 21487. This 30-page publication provides detailed instructions for conducting sustainable firewood harvests on oak woodland properties, including how to determine the wood volume in a tree, deciding whether or not to cut, and marking stands for firewood harvests. Available from the UC ANR Publications Web site at http://anrcatalog.ucdavis.edu.

Tinnin, P., and G. Fiusti, eds. 1996. Guidelines for managing California's hardwood rangelands. Oakland: University of California Division of Agriculture and Natural Resources, Publication 3368. This 180-page publication will help landowners and managers of hardwood rangeland properties develop management plans that maintain the profitability of their properties, while at the same time sustaining ecological values. Published by the Integrated Hardwood Range Management Program, the California Department of Fish and Game, and the California Department of Forestry and Fire Protection, this guideline will lead the reader through an evaluation of goals and objectives for their properties and presents a variety of management strategies to achieve these. See order instructions on the IHRMP Web site at http://danr.ucop.edu/ihrmp/. Or see "For Further Information" below.

\section{FOR FURTHER INFORMATION}

To order these products, visit our online catalog at http://anrcatalog.ucdavis.edu. You can also place orders by mail, phone, or FAX, or request a printed catalog of publications, slide sets, CD-ROMs, and videos from

University of California

Agriculture and Natural Resources

Communication Services

6701 San Pablo Avenue, 2nd Floor

Oakland, California 94608-1239

Telephone: (800) 994-8849 or (510) 642-2431

FAX: (510) 643-5470

E-mail inquiries: danrcs@ucdavis.edu 
An electronic version of this publication is available on the ANR Communication Services Web site at http://anrcatalog.ucdavis.edu.

\section{Publication 8263}

ISBN-13: 978-1-60107-484-3

(C) 2007 by the Regents of the University of California, Division of Agriculture and Natural Resources. All rights reserved.

To simplify information, trade names of products have been used. No endorsement of named or illustrated products is intended, nor is criticism implied of similar products that are not mentioned or illustrated.

The University of California prohibits discrimination or harassment of any person on the basis of race, color, national origin, religion, sex, gender identity, pregnancy (including childbirth, and medical conditions related to pregnancy or childbirth), physical or mental disability, medical condition (cancer-related or genetic characteristics), ancestry, marital status, age, sexual orientation, citizenship, or status as a covered veteran (covered veterans are special disabled veterans, recently separated veterans, Vietnam era veterans, or any other veterans who served on active duty during a war or in a campaign or expedition for which a campaign badge has been authorized) in any of its programs or activities. University policy is intended to be consistent with the provisions of applicable State and Federal laws.

Inquiries regarding the University's nondiscrimination policies may be directed to the Affirmative Action/Staff Personnel Services Director, University of California, Agriculture and Natural Resources, 1111 Franklin Street, 6th Floor, Oakland, CA 94607-5201, (510) 987-0096. For a free catalog of other publications, call (800) 994-8849. For help downloading this publication, call (530) 297-4445.

This publication has been anonymously peer reviewed for technical accuracy by University of California scientists and other qualified professionals. This review process was managed by the ANR Associate Editor for Natural Resources.

pr-8/07-LR/CM 